\title{
Immunomodulatory agents for COVID-19 treatment: possible mechanism of action and immunopathology features
}

\author{
Foad Rommasi $^{1}$ (D) Mohammad Javad Nasiri $^{2}$ (D) $\cdot$ Mehdi Mirsaeidi $^{3}$ (D)
}

Received: 13 August 2021 / Accepted: 1 December 2021 / Published online: 11 January 2022

(c) The Author(s), under exclusive licence to Springer Science+Business Media, LLC, part of Springer Nature 2021

\begin{abstract}
The novel coronavirus pandemic has emerged as one of the significant medical-health challenges of the current century. The World Health Organization has named this new virus severe acute respiratory syndrome coronavirus 2 (SARS-CoV-2). Since the first detection of SARS-CoV-2 in November 2019 in Wuhan, China, physicians, researchers, and others have made it their top priority to find drugs and cures that can effectively treat patients and reduce mortality rates. The symptoms of Coronavirus Disease 2019 (COVID-19) include fever, dry cough, body aches, and anosmia. Various therapeutic compounds have been investigated and applied to mitigate the symptoms in COVID-19 patients and cure the disease. Degenerative virus analyses of the infection incidence and COVID-19 have demonstrated that SARS-CoV-2 penetrates the pulmonary alveoli's endothelial cells through Angiotensin-Converting Enzyme 2 (ACE2) receptors on the membrane, stimulates various signaling pathways and causes excessive secretion of cytokines. The continuous triggering of the innate and acquired immune system, as well as the overproduction of pro-inflammatory factors, cause a severe condition in the COVID-19 patients, which is called "cytokine storm". It can lead to acute respiratory distress syndrome (ARDS) in critical patients. Severe and critical COVID-19 cases demand oxygen therapy and mechanical ventilator support. Various drugs, including immunomodulatory and immunosuppressive agents (e.g., monoclonal antibodies (mAbs) and interleukin antagonists) have been utilized in clinical trials. However, the studies and clinical trials have documented diverging findings, which seem to be due to the differences in these drugs' possible mechanisms of action. These drugs' mechanism of action generally includes suppressing or modulating the immune system, preventing the development of cytokine storm via various signaling pathways, and enhancing the blood vessels' diameter in the lungs. In this review article, multiple medications from different drug families are discussed, and their possible mechanisms of action are also described.
\end{abstract}

Keywords SARS-CoV-2 · Pathophysiology · COVID-19 treatment · Inflammatory responses $\cdot$ Immunosuppressive agents · Cytokine storm

\section{Introduction}

The newest member of the coronavirus family, named SARSCoV-2 or formerly 2019 novel coronavirus (2019-nCoV)—a beta-coronavirus from RNA viruses-is a causative agent of a crucial respiratory infection known as COVID-19 in

Foad Rommasi

f.ramasi@mail.sbu.ac.ir

$1 \quad$ Faculty of Life Sciences and Biotechnology, Shahid Beheshti University, Tehran, Iran

2 Department of Microbiology, School of Medicine, Shahid Beheshti University of Medical Sciences, Tehran, Iran

3 Department of Pulmonary and Critical Care, Miller School of Medicine, University of Miami, Miami, FL, USA patients [1]. The genetic material of SARS-CoV-2, which is attached to the virus's Nucleocapsid protein, consists of 26 to $32 \mathrm{Kbps}$ [1,2]. This virus was first identified in December 2019 in Wuhan, Hubei Province, Mainland China [3]. In March 2020, SARS-CoV-2 spread to more than 114 countries, prompting the World Health Organization to announce a pandemic for SARS-CoV-2 [4]. The virus is hypothesized to have been originally a zoonotic virus transmitted from animals to humans, although human-to-human transmission of the 2019-nCoV has led to its spread [5].

Coronaviruses are generally classified into four primary groups: alpha, beta, delta, and gamma [6]. SARS-CoV-2, as a beta-coronavirus, has various structural proteins. Spike protein, nucleocapsid protein, and membrane proteins are among the most crucial structural proteins of SARS-CoV-2 
that can stimulate the immune system [1,2]. The virus enters host cells through endocytosis by binding to AngiotensinConverting Enzyme 2 (ACE2) receptors present on the cell membrane and begins to replicate by exploiting the host cell replication machine [7]. In addition to the lungs, ACE2 is present on the cell membrane of other tissues such as the heart, kidneys, testes, and intestines, enabling SARS-CoV-2 to infect these organs $[8,9]$.

COVID-19 is generally considered a respiratory disease that involves the lungs. It can cause disparate symptoms such as fever, dry cough, fatigue and headache. [10]. Although in most patients SARS-CoV-2 results in mild symptoms, however in some patients, this infection may cause acute and widespread damages such as septic shock, acute kidney injury (AKI) and acute respiratory distress syndrome (ARDS) [11, 12]. In COVID-19, like other infectious diseases, fever occurs due to the release of various cytokines and their effects on the hypothalamus. All symptoms of SARS-CoV-2 infection occur due to the stimulation of the immune system and activation of innate and acquired immunity against this virus [13]. When SARS-CoV-2 enters the body, it is firstly detected by innate immunity cells and their receptors (such as Toll-like receptor 3 (TLR-3)) [14] which results in the formation of NLRP3 inflammasomes and inflammatory responses [15]. CD4 + and CD $8+$ cells have a remarkable role in the synthesis of cytokines and chemokine and acquired immunity activation [16]. CD8 + cells clear viruses from the body by activating cytotoxic pathways [17]. CD4 + cells are involved in synthesizing and releasing chemokines and cytokines from the immune cells by differentiating into T-helper 1 cell (Th1) [18]. Cytokines and various compounds such as interleukins (ILs)- $1 \mathrm{\alpha} / \beta, \mathrm{IL}-2$, IL- 4, IL-6, IL-10, IL-17 and TNF-a. [19], are produced when cells get infected by SARS-CoV-2, culminating in the migration of lymphocytes and leukocytes to the lesion site [20]. This mechanism can lead to the overproduction of cytokines (known as cytokine storm), damage to normal lung cells, destruction of lung tissue, and even critical condition or death [13, 18]. A detailed account of COVID-19 impacts on the immune system as well as its immunopathology ramifications is illustrated in Fig. 1.

It is hypothesized that the application of immunomodulatory drugs can neutralize these cytokines or prevent critical conditions in patients by inhibiting the function of harmful molecules [21]; for this reason, these drugs have been considered for the treatment of COVID-19. So far, only one particular antivirus drug called Molnupiravir is suggested for COVID-19 treatment [22]. However, various antiviral agents with different mechanisms of action have been used for COVID-19 patients in clinical trials, which sometimes have been effective and sometimes ineffective [23]. This review paper is aimed at summarizing the immunomodulatory drugs administered to treat COVID-19 or alleviate its symptoms. It also tries to investigate the possible mechanism of action and clinical trials implemented to express their effectiveness or ineffectiveness. In the following section, the most critical immunomodulatory agents from different drug families are reviewed.

\section{Main text}

The following describes the possible mechanism of action and pharmacological properties of some critical agents from various family drugs, which are discussed or seem to be effective for modulating immune system responses after SARS-CoV-2 infection.

\section{Anakinra}

Anakinra is an anti-inflammatory drug that is primarily applied to treat Rheumatoid arthritis (RA). Interleukin-I and other cytokines are involved in the development of RA [24]. This issue has drawn the attention of scientists and researchers to anti-rheumatoid medications because in COVID-19 infection, like RA [25], over activation of the immune system and overproduction of cytokines such as IL-1 worsen the patient's condition [26]. In 1980, after discovering Interleukin-I Receptor Antagonist (IL-I Ra) — which is naturally present in the synovial membrane-various proteins and antagonistic compounds were adopted for RA treatment via inhibiting the function of interleukins or other pathways $[27,28]$. After the detection of endogenous IL-1Ra, it was isolated. After the purification and determination of its amino acid sequence, its mRNA and synthesized cDNA were inserted into the Escherichia coli (E. coli) genome for protein expression [29]. This produced human recombinant protein in E. coli, which had IL-1R antagonistic properties, was called Anakinra. This therapeutic protein with a molecular weight of about $17 \mathrm{kDa}$ can exert its effect by binding to Interleukin-I Receptors (IL-1Rs) that are present on the surface of T cell membranes [30]. It is primarily capable of inhibiting the function of both IL-1 $\alpha$ and IL-1 $\beta$. Anakinra's mechanism of action against IL-1 is conducted by suppressing the natural binding of IL-1 to IL-1Rs and IL-1 accessory portion (IL-1Acp) that are present on the exterior of $\mathrm{T}$ cell membranes. In fact, in the absence of Anakinra, IL-1 binds to IL-1R and IL-1Acp to activate intracellular signaling pathways and stimulates T cells [28]. IL-1 can also stimulate the production of Prostaglandin E2 (PEG2) or metalloprotease enzymes and the degradation of peptidoglycans [28, 31]. Anakinra also inhibits IL-1-induced hyaluronic acid (HA) production in cartilage [32]. It is hypothesized that these positive effects of Anakinra can effectively block the destruction of lung tissue and its harmful heterogeneous regeneration. Various cohort studies have been conducted 


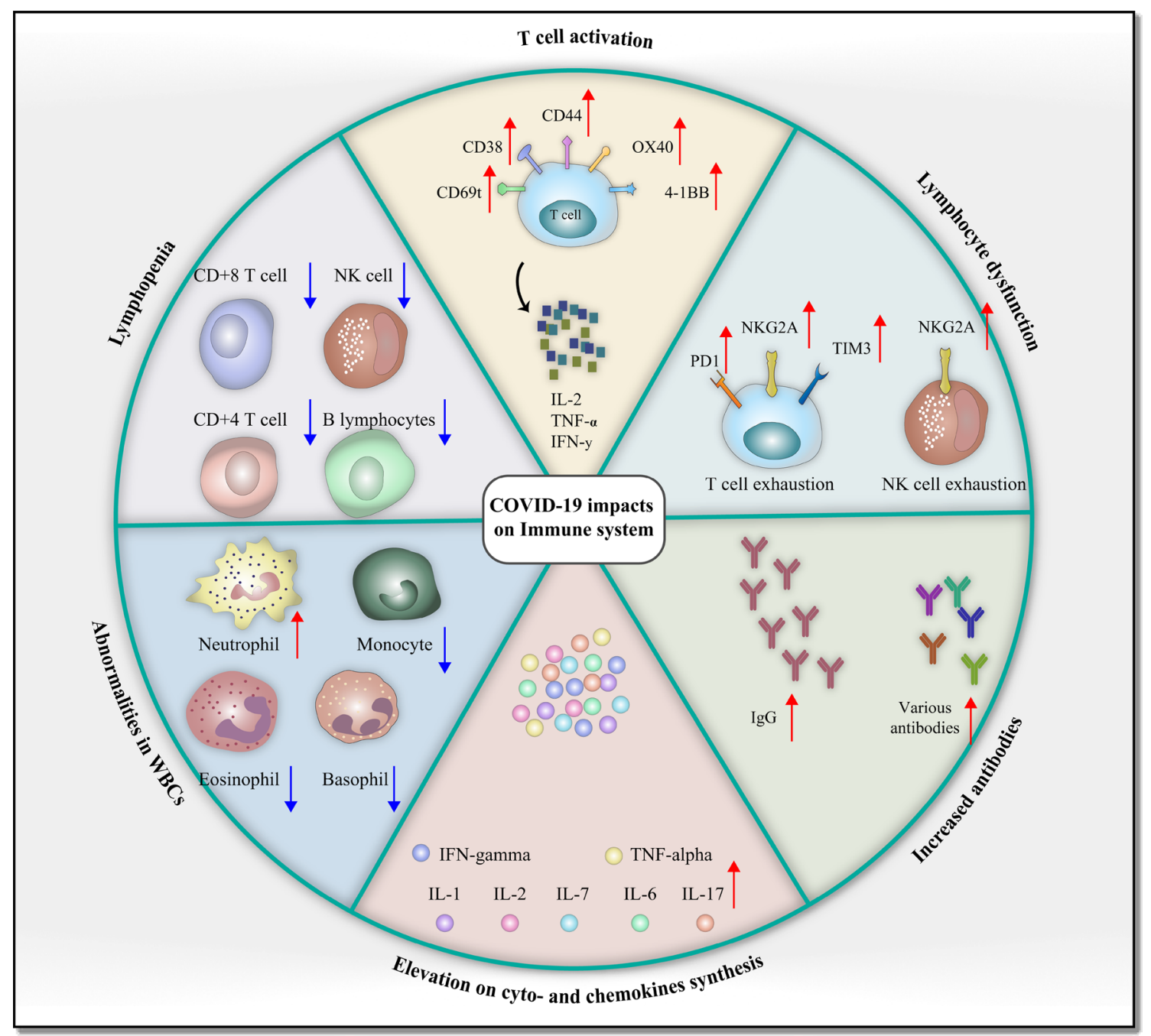

Fig. 1 The investigation of COVID-19 immunopathology indicated that the infected individuals' immune patterns include increased activation of $\mathrm{T}$ cells, which is accomplished by the higher expression of some receptors in the $\mathrm{T}$ cell membrane. Lymphopenia is a critical immune pattern in COVID-19 patients. Overproduction of some

on the application of this drug in COVID-19 patients. In one of these studies, the utilization of Anakinra reduced the requirement of mechanical ventilation in patients and also decreased the demand for ICU hospitalization and fatality rate [33]. This cohort study [33], along with available information on the mechanism of action in this therapeutic agent as well as other studies, has set forth Anakinra as an appropriate candidate to hinder the destructive effects of the cytokine storm.

\section{Tocilizumab}

As noted before, Interleukin 6 (for short, IL-6) is a significant pro-inflammatory protein and cytokine that can be freely present in serum [34]. The concentration of this cytokines and chemokines caused by SARS-CoV-2 infection may result in cytokine storm and even ARDS. Lymphocytes dysfunction, abnormalities in WBCs, and increased antibodies are also other important immunopathological patterns in COVID-19 that can be observed in detail

cytokine in a normal situation is not high in a healthy person. Its concentration, however, increases following an infection or inflammation. This interleukin has an influential role in initiating and inducing biochemical reactions and can regulate inflammation and the immune response in two ways [35]: Classical and Trans pathways. In the classical pathway, IL-6 attaches to the membrane-bound receptor for IL-6 (mbIL-6), which is present on various immune cells' membranes. Then this complex acts as a ligand and binds to a glycoprotein structure called Glycoprotein-130 (gp-130) [36]. Next, it stimulates the innate immune response (via macrophages and neutrophils) and acquired immunity (through $\mathrm{T}$ and $\mathrm{B}$ cell stimulation) [37]. In the Trans pathway, IL-6 can cause the production of large volumes of pro-inflammatory agents by attachment to a structure called soluble 
receptor for IL-6 (srIL-6), which is amply present on the surface of endothelial cells (rather than immune cells) [38]. Tocilizumab, a humanized monoclonal antibody, can act as an antagonist against IL-6 and bind to both mIL-6R and sIL$6 \mathrm{R}$ receptors to prevent IL-6 from attaching to them. This attachment ultimately results in the prevention of signaling pathways leading to inflammation. The United States Food and Drug Administration (US-FDA) approved phase III of Tocilizumab's clinical trial for COVID-19 patients [39]. Nevertheless, extensive studies are still required to evaluate the effectiveness of Tocilizumab and its mechanism of action.

\section{Infliximab}

Infliximab is a chimeric monoclonal antibody with the molecular formula $\mathrm{C}_{6428} \mathrm{H}_{9912} \mathrm{~N}_{1694} \mathrm{O}_{1987} \mathrm{~S}_{46}$, which is capable of binding to either soluble or membrane-bound TNF-a [40]. The attachment of Infliximab to soluble TNF-a prevents it from binding to the cellular receptors and suppresses the initiation of signaling cascades caused by this binding. The attachment of this therapeutic agent to membrane-bound TNF-a has also been proved to cause cell lysis through different immunological mechanisms such as antibody-dependent cellular cytotoxicity (ADCC) [40, 41]. This medication is vastly applied for treating RA via suppressing the harmful effects of cytokines [42]. The utilization of Infliximab can also reduce the concentration of C-Reactive Protein (CRP) as well as IL-6 in the patients' blood [43] and appears to be able to prevent cytokine storms in COVID-19 patients. The synovial biopsy also indicated that consumption of Infliximab could reduce TNF-a production followed by a reduction in IL-1 synthesis [44, 45]. These findings suggest that Infliximab may be a viable option for preventing cytokine storm incidence and the patients' severe condition. Finally, Mohsen Farrokhpour et al. [46] investigated the impact of Infliximab prescription for COVID-19 patients. All patients in this study were in severe condition and admitted to the ICU. This study revealed that the patients who received Infliximab survived more than the ones in the control group (63\% vs. $37.2 \%$, respectively) [46]. In this study, the mortality rate was reported to be only $37 \%$ in the Infliximab group, while it was $62.8 \%$ for the control group [46]. However, further studies are warranted to determine the precise efficacy of this drug in the treatment of COVID-19 patients.

\section{Baricitinib}

As mentioned earlier, SARS-CoV-2 results in cytokine storm and severe inflammation by stimulating the secretion of pro-inflammatory factors [26, 47]. Baricitinib, under the commercial name of Olumiant, is a Janus kinase (JAK) $1 / 2$ inhibitor drug applied to treat RA. It has potent anti-inflammatory properties and is hypothesized to have off-target antiviral impacts against SARS-CoV-2. For this reason, it has been introduced as a suitable candidate for treating COVID-19 [48, 49].

In a clinical trial conducted by Boghuma K. Titanji et al. [50], 2 to $4 \mathrm{mg}$ of Baricitinib with 200 to $400 \mathrm{mg}$ of Hydroxychloroquine were administered to 13 out of 15 patients daily. The inflammatory factors' levels were monitored in all patients. The results demonstrated that in 13 out of 15 patients, the levels of inflammatory factors such as CRP, IL-6, and erythrocyte sedimentation rate (ESR) diminished. Moreover, the fever in these patients disappeared during the treatment period, and their body temperature decreased [50]. The Baricitinib action mechanism in COVID-19 may be such that it interferes with the entry of the virus into the host cell. This drug disrupts the process of virus endocytosis into the cell by acting on two numb-associated kinase enzymes, thus preventing SARS-CoV-2 from penetrating the host cell $[50,51]$. However, the utilization of this agent in COVID19 patients has been associated with concerns. Interferon is one of the essential proteins and a practical component of the innate immune system that prevents the virus from replicating in the cell and spreading in the body. By activating the JAK-STAT signaling pathway (in which JAK-1 and JAK-2 enzymes play a significant role), the expression of interferon genes increases, resulting in viral clearance [52]. Baricitinib, as a Janus kinase (JAK) inhibitor, can disrupt the JAK-STAT pathway and prevent an adequate antiviral response; thus, it potentially can increase the severity of COVID-19 in patients [50,53]. Therefore, the consumption of this agent must be done very cautiously.

\section{Interferon I- $\beta 1 \mathrm{a}$}

Interferon- $\beta$ is type- 1 interferon that is utilized for multiple sclerosis (MS) treatment. It is indicated that it can positively influence the elimination of the virus from nasopharyngeal sampling swabs in phase II clinical trials [54, 55]. It can be utilized subcutaneously (S.C.) and intravenously (I.V.). Recent studies have determined that the use of IFN- $\beta 1$ a and IFN- $\beta 1 \mathrm{~b}$ has the same promising effects on COVID-19 patients because, in both states, it launches specific and identical pathways against SARS-CoV-2 [56]. However, S.C and I.V. administration of interferon results in entirely different outcomes in patients. The utilization of IFN intravenously increases its serum concentration. Studies have revealed that this drug's subcutaneous injection reduces its bioavailability and serum concentration and thus decreases its effectiveness. The IFN serum concentration in people receiving the subcutaneous administration has been approximately $1 / 3$ of the patients who have had the intravenous injections [57]. Elimination of interferon- $\beta 1$ a occurs by its binding to the interferon- $\alpha / \beta$ receptor (IFNAR). Subcutaneous 
administration of this drug reduces the rate of its uptake by the lymphatic system. This reduction causes this drug's plasma concentration to remain high for an extended period. In comparison, intravenous infusion causes rapid removal of IFN from the blood and body fluid [58]. Nevertheless, the main reason for utilizing type- 1 interferons intravenous injection instead of subcutaneous in some patients is its higher bioavailability. The best and golden time of interferon beta 1a injection to the patients with COVID-19 is immediately after the diagnosis and at the beginning of the infection. Studies have shown that subcutaneous injection is effective in mild condition patients, while intravenous injection is recommended in patients in critical condition [54]. Interferon-beta 1a increases the concentration of CD73 in the pulmonary capillaries. CD73 is an enzyme that plays a vital role in modulating lung vessel diameter, especially in hypoxic conditions, and affects pulmonary vascular integrity. This enzyme also cleaves pro-inflammatory ATP and pre-thrombotic ADP. It converts ATP and ADP into the antiinflammatory adenosine monophosphate (AMP), clearing them (which causes inflammation) from the blood and thus preventing ARDS [59]. This drug can reduce the secretion of IL-6 and IL-8. It also strengthens the immune system while reducing the tissue damage (by decreasing neutrophil migration) $[60,61]$.

Recent studies have demonstrated that corticosteroids block the function of IFN and reduce the severity of CD73 expression [62]. These investigations suggest that interferon beta and corticosteroids should not be used concomitantly as their functional pathways may have unintended drug interactions [63].

\section{Statins}

Statins are among the most well-known and accessible [64] therapeutic agents applied to the lower blood lipids that inhibit cholesterol synthesis. These medications have pleiotropic effects on inflammation and its pathways, which, along with the lipid-lowering impact, improve the patient's cardiovascular condition. These drugs also have immunomodulatory consequences, exerting these lipid-lowering effects through influencing some mechanisms. The mechanisms include the antigen presentation and production of chemokines and cytokines, as well as the impact on the migration and maturation of the immune cells [65]. The primary action mechanism of this drug is inhibiting the synthesis of isoprenoids. Isoprenoids are essential constituents of GTPase enzymes. Statins cause a reduction in the concentration of Rho and Rac enzymes by inhibiting isoprenoids' production, which leads to the downregulation of pro-inflammatory factors' genes like NF-kB [66]. As stated, Beta-coronaviruses, like influenza viruses, stimulate the production of large amounts of pro-inflammatory factors, which cause cytokine storms, weakening the immune system and ARDS [65]. Statins, in addition to reducing the production of pro-inflammatory factors via the above-mentioned mechanism, prevent severe pneumonia and hypoxia by stabilizing the expression of the MYD88 gene. MYD88 gene codes a protein that activates the NF-kB gene [67]. Research has demonstrated that the presence of atorvastatin-a drug from the statins family - at a concentration of $0.1 \mu \mathrm{M}$ in plasma for $48 \mathrm{~h}$ intensely reduces the activation of NF-kB and suppresses inflammation. In order to reach the concentration of $0.1 \mu \mathrm{M}$ in atorvastatin of the blood, about $40 \mathrm{mg}$ of oral consumption of atorvastatin once a day is required [68]. After penetrating the cell via ACE2 receptor, SARS-CoV-2 reduces the expression of this receptor on the cell membrane, which can increase the concentration of angiotensinII in the extracellular fluid and cause tissue damage. Atorvastatin enhances the intensity of ACE2 expression in the cell membrane and prevents the accumulation of angiotensin-II and tissue damages [69]. From a pharmacokinetic point of view, statins have hepatic metabolism and are affected by the CYP3A4 enzyme complex. The half-life of these drugs is about $1.4 \mathrm{~h}$, and they are finally excreted through the kidneys or intestines [70]. These medications are safe, inexpensive and affordable, making them suitable treatments for COVID-19 patients. Their immunomodulatory influences on COVID-19 themselves require proper and sufficient in vitro and in vivo investigations.

The six drugs discussed so far each has a specific receptor on different cells membrane, enabling them to bind to these receptors to exert their effects. This issue is schematically illustrated in Fig. 2.

\section{Dexamethasone}

Recently, many studies have reported the efficacy of Dexamethasone in treating patients with severe COVID-19, resulting in reduced mortality and morbidity among these patients [71]. As mentioned, SARS-CoV-2 causes respiratory infection, and this disease can involve other organs [72]. A substantial number of activated $\mathrm{T}$ cells and cytokinemediated antibody extraction are required in order to clear the virus from tissues [73].

The US-FDA approved Dexamethasone in 1958 as a synthetic drug from the corticosteroid family. As a broadspectrum immunosuppressant, it reduces inflammation and decreases immune system activity [74]. Dexamethasone, which is 30 times more immunosuppressant and active than cortisone, reduces the overproduction of cytokines. On the other hand, Dexamethasone may increase the risk of secondary infection by suppressing the $\mathrm{T}$ and $\mathrm{B}$ mature cells, which are vital to fighting the pathogens. It also interferes with NK cells and macrophages' functions, which are responsible for clearing the body from pathogens $[74,75]$. The 


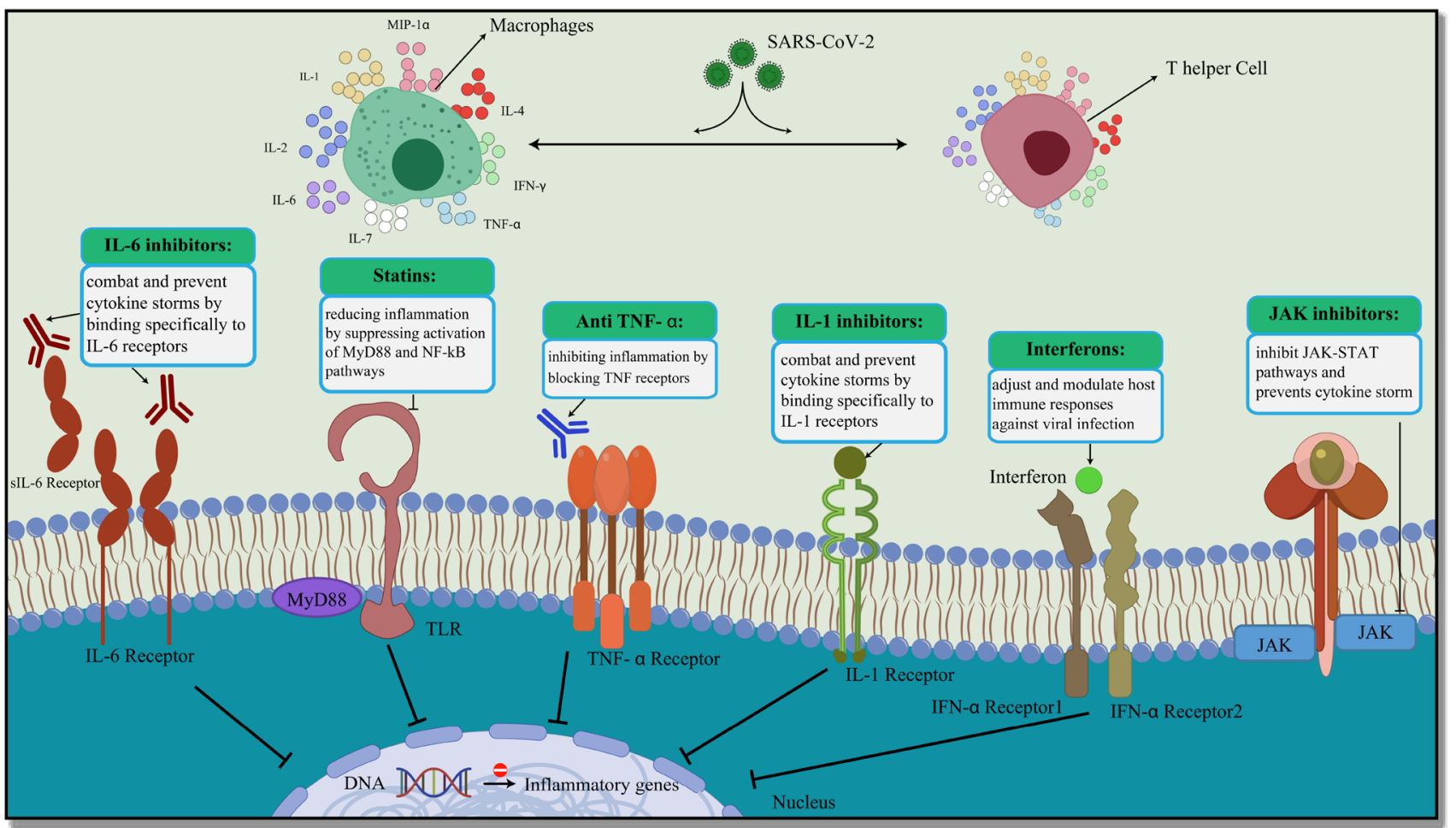

Fig. 2 Various mAbs or antagonists are utilized for COVID-19 treatment. These agents have different receptors on the host cell surface. The binding of these therapeutic agents to their cellular receptors is usually accompanied by the activation of intracellular pathways,

greatest randomized control trial (RCT) in the world, called the RECOVERY trial, was performed on 2104 patients in the United Kingdom. The elicited results demonstrated a reduction in mortality in critical cases and patients [76]. Crucial producers of pro-inflammatory cytokines that cause cytokine storms are mast cells, which together with macrophages cause overproduction of pro-inflammatory factors such as IL- $1 \beta$, IL- 6 , and TNF- $\alpha$ and may also result in blood agglutination and organ failure [77]. By suppressing this mechanism, Dexamethasone can prevent critical conditions in COVID-19 patients and reduce the mortality rate. Despite all this, it is advised to use Dexamethasone in the short term and severe patients. However, further research is required to understand the exact action mechanism of Dexamethasone [71].

\section{Famotidine}

As mentioned, labrocytes (mast cells) are absolutely crucial in developing hyper-inflammation in patients with COVID19 [78]. These cells trigger other molecular pathways by secreting histamines. Histamines are effective in causing inflammation, increasing the volume and blood flow in the arteries, and enhancing capillaries' permeability. Histamines which ultimately reduces the expression of pro-inflammatory genes such as NF-K $\beta$. Macrophages and T cells are vastly impacted by immunomodulatory drugs administration

are divided into two subgroups: $\mathrm{H} 1$ and $\mathrm{H} 2$. Famotidine is prescribed as a Histamine- 2 receptor antagonist to reduce gastric acid secretion that causes pain and burning [79]. Histamines are related to inflammation in patients with SARS-CoV-2 infection and exert their effect by influencing the activated T cells [80]. Histamines as biological molecules can also impact leukocytes and result in the secretion of cytokines and inflammation, thus causing damages to the lungs [81]. Famotidine can prevent the occurrence of cytokine storms and death in patients by blocking these signaling pathways. A cohort study on 1,620 patients has documented that 84 of the patients who received famotidine demonstrated that this agent could efficiently block histamine-mediated inflammation and reduce mortality rate and intubation demand in the patients [82].

\section{Naproxen}

Non-steroidal anti-inflammatory drugs (NSAIDs) are therapeutic agents that reduce inflammation by acting on the molecular pathways [83]. The liver mainly metabolizes these drugs. Naproxen is a non-selective COX inhibitor and is one of the compounds related to propionic acid. Propionic acid is essential in inflammation incidence because it triggers the 
molecular pathways that reduce prostaglandin production from arachidonic acid, thus resulting in inflammation reduction via this mechanism $[84,85]$. As a non-selective inhibitor, Naproxen effectively affects both COX-1 and COX-2 complex enzymes and shows its effect by reducing particular biological molecules synthesis [86]. As mentioned, this drug is metabolized in the liver by the CYP1A2 and CYP2C9 enzyme complexes. Some studies have reported that Naproxen is safe for patients with COVID-19. Its administration is accompanied by no particular or severe adverse effects [87]. This drug's precise mechanism on COVID-19, however, is not particularly known and requires further studies and clinical trials. Nonetheless, it is speculated that Naproxen is effective in decreasing ARDS and reducing patient mortality.

Figure 3 exhibits the occurrence of COVID-19 and its different phases in SARS-CoV-2 infected individuals. The mechanism of cytokine storm incidence and promising therapeutic agents that can influence this condition are demonstrated in Fig. 3.

\section{Colchicine}

Colchicine is an alkaloid chemical compound with the molecular formula $\mathrm{C} 22 \mathrm{H} 25 \mathrm{NO}$, naturally synthesized by Colchicum genus plants. It is clinically utilized because of its anti-inflammatory impacts on various diseases such as gout, familial Mediterranean fever, Behcet's disease, and other inflammatory diseases and fibrotic disorders [88]. Colchicine has diverse mechanisms of action that ultimately reduce the inflammation and prevent acute conditions. Colchicine manifests its anti-inflammatory effects by acting on the immune system [89]. One function of Colchicine in the innate immune system is the suppression of neutrophil chemotaxis. In fact, Colchicine suppresses neutrophil chemotaxis by inhibiting the release of crystal-derived chemotactic factors from cell lysosomes [90].

On the other hand, in animal studies, Colchicine has been shown to stimulate the maturation of dendritic cells into various kinds of $\mathrm{T}$ cells by activating signaling pathways and increasing antigen presentation [91]. The stimulation of dendritic cells by Colchicine has also been reported in different studies $[92,93]$. Colchicine also has anti-fibrotic influences, affecting intestinal tissue by triggering the expression of Bcl-2 genes and silencing caspase-3 genes [94]. In addition, it also suppresses lung inflammation and fibrosis by inhibiting the differentiation and growth of myofibroblasts via the Rho/Serum response factor (SRF)-dependent signaling pathway [95]. It can also block NLRP3 inflammasome and caspase-I activity by impacting the ROS system [96]. Recently, a study examined the effect of Colchicine on non-hospitalized COVID-19 patients [97]. The elicited outcomes of this study indicated that Colchicine could reduce hospitalization or mortality rates among non-hospitalized

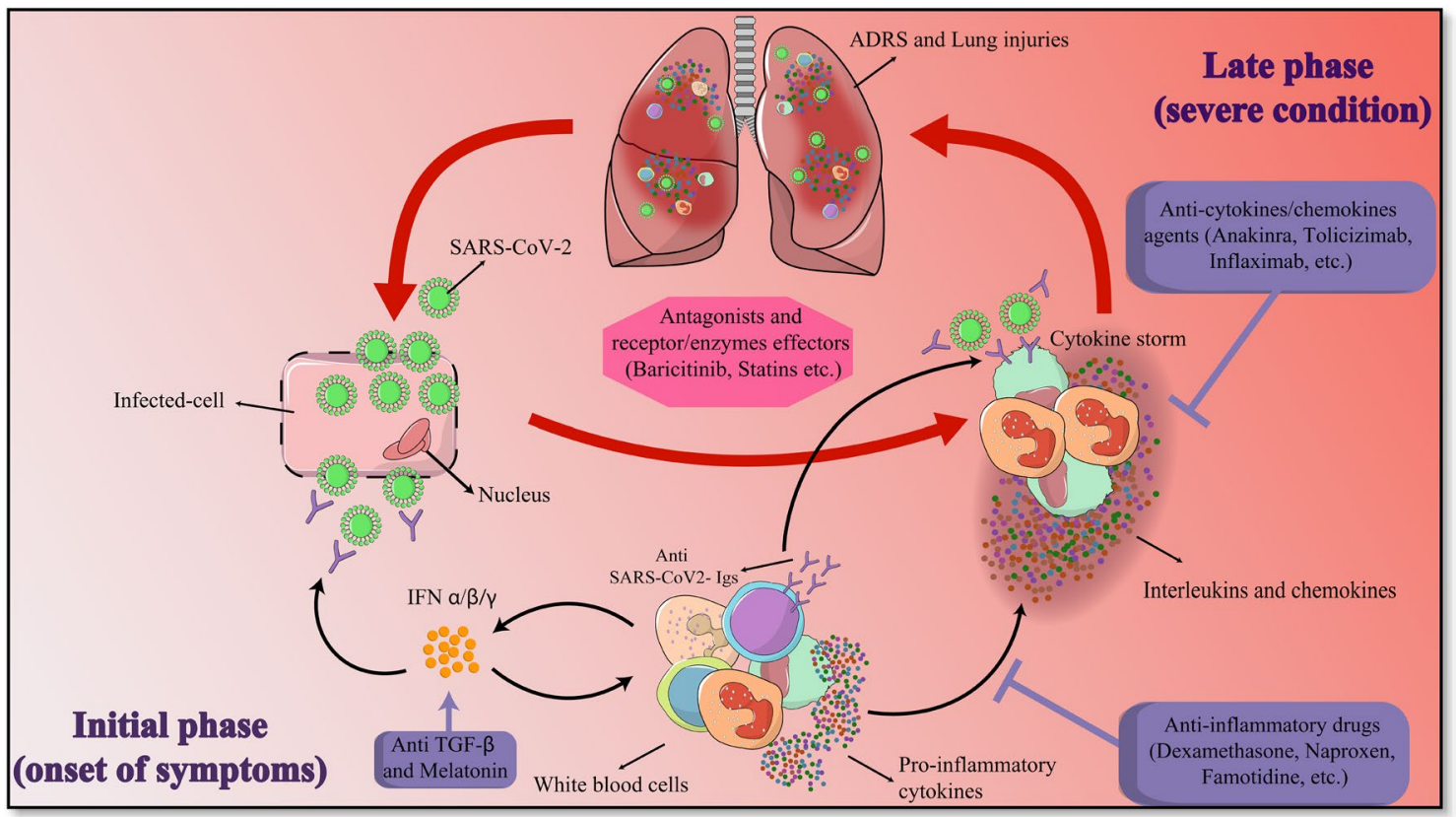

Fig. 3 After the initiation of COVID-19, which is caused by infection of lung epithelial cells by SARS-CoV-2, some antiviral responses such as IFN- $\alpha / \beta / \gamma$ were started. These primary antiviral responses result in the apoptosis of infected cells and the production of proinflammatory cytokines, which cause virus elimination. Excessive synthesis of cytokines and chemokines may lead to critical conditions like ARDS and lung injuries. The application of immunomodulatory drugs can adjust immune system responses and impede critical conditions in COVID-19 patients 
patients [97]. However, at the beginning of the SARS-CoV-2 pandemic, Medine Cumhur Cur et al. [98] noted that administering Colchicine may not have positive influences, and it could be even harmful [98]. Therefore, more clinical trials in this area are needed to understand the colchicine mechanism of action. The possible action mechanism and various functions of Colchicine are illustrated in Fig. 4.

\section{Melatonin}

Melatonin or N-acetyl-5-methoxytriptamin is a monomeric tryptophan-derived neurotransmitter-like compound that has hormonal activities [99]. The chemical formula of Melatonin, which is mainly secreted from the enigmatic pineal gland in the brain, is $\mathrm{C}_{13} \mathrm{H}_{16} \mathrm{~N}_{2} \mathrm{O}_{2}$ [100]. It has an influential role in regulating the wake-sleep cycle, circadian rhythm, and body's biological clock [101, 102]. Melatonin is synthesized from tryptophan through a cascade of enzymatic reactions in four steps, which contains hydroxylation, decarboxylation, $\mathrm{N}$-acetylation, and methylation reactions, respectively $[100,103]$. Melatonin secretion and its nexus with age were surveyed in a study by Haruo Iguchi et al. [104], which observed a reverse correlation between melatonin secretion and age. Thus, the brain-immune system axis and its interactions have been indicated to be required for appropriate body responses to pathogens' invasions [105]. Melatonin can play a significant role in the interactions of the brain-immune system. For example, this protein can increase IFN- $\gamma$ synthesis but not IL- 4 by affecting peripheral mononuclear blood cells [106]. It has been proved that interferon-gamma has a prominent role in combating viral agents [107]. It has also been unveiled that viral infections can be associated with an elevation in reactive oxygen species (ROS) and/or reactive nitrogen species (RNS) [108]. Oxidative stress in respiratory viral infections can cause extensive damage to lung tissue [109]. Melatonin has cogent antioxidant properties, and each melatonin molecule can bind to 10 oxidant agents; other antioxidant compounds

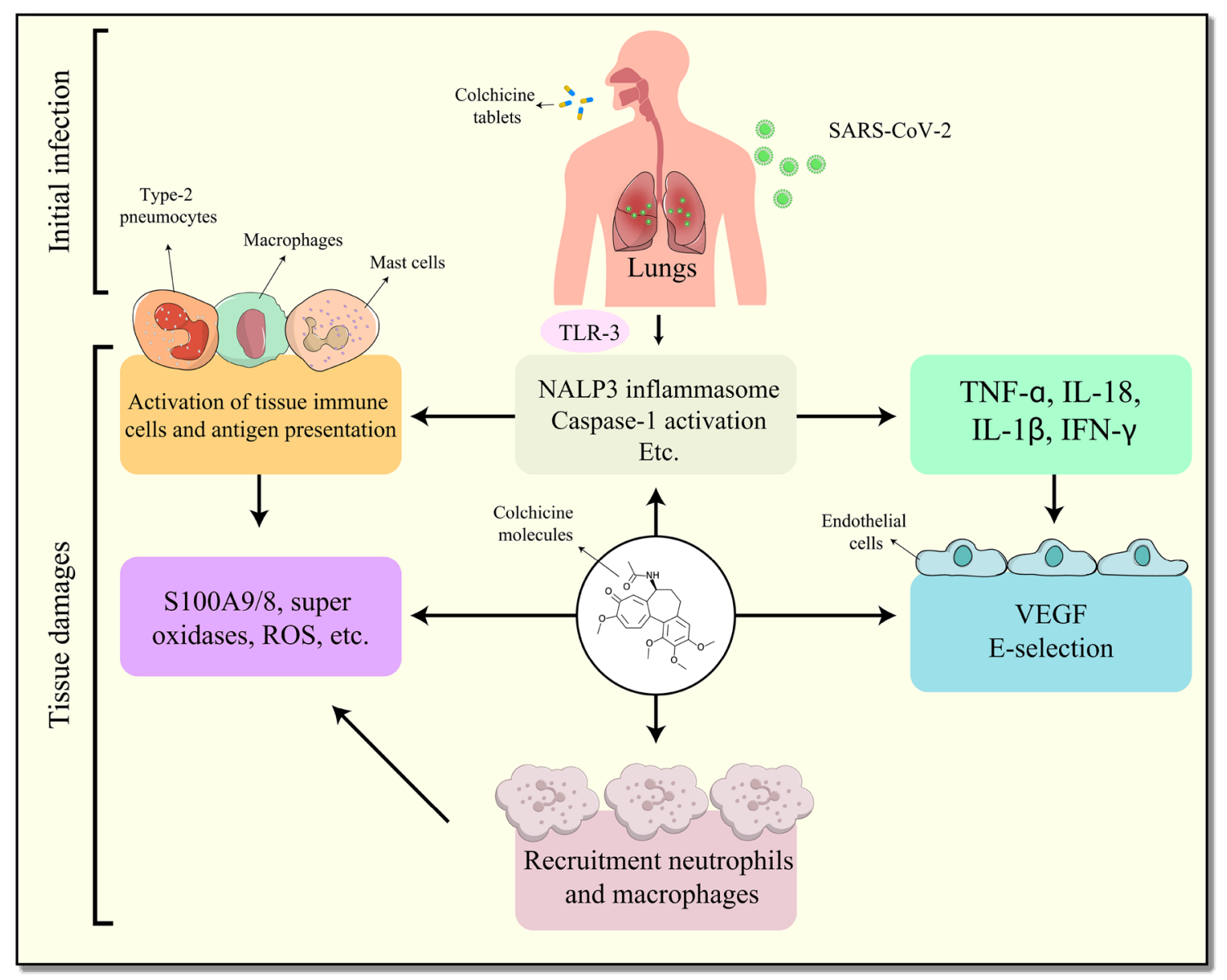

Fig. 4 SARS-CoV-2 is recognized by innate immunity receptors such as TLR3 when it enters the body. The recognition of 2019-nCoV by TLR3 results in the activation of other immune components. Colchicine can influence various inflammatory cascades and inhibit inflam- mation via a different process. It also affects leucocytes' recruitment, reduces ROS synthesis, and positively affects endothelial cells, alleviating tissue damage to the lungs 


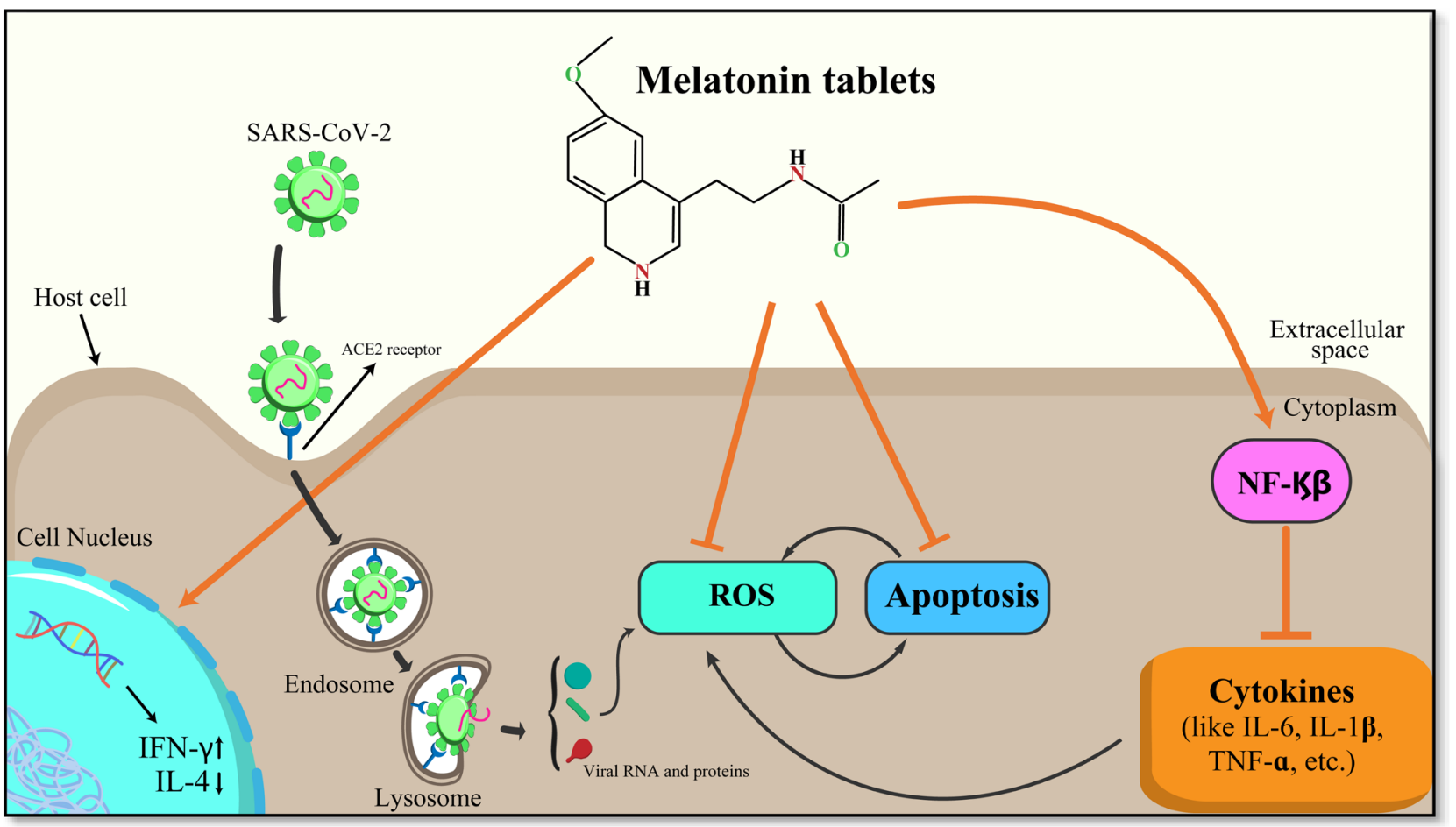

Fig. 5 As stated, Melatonin as an Acetamide hormone can be consumed orally in COVID-19 patients. Melatonin molecules are capable of influencing various pathways after entering the cell. It can decrease ROS/RNS synthesis and impact host cell apoptosis. It is also able to

(e.g., vitamins $\mathrm{C}$ and $\mathrm{E}$ ) usually can bind to only one oxidant molecule [110]. Furthermore, melatonin prescription in MS patients has been reported to be beneficial as Melatonin can act as an antagonist and reduce the activity of cell-mediated immunity [105, 111]. These cases, along with the regulation of sleep time and relief of insomnia symptoms in COVID19 patients, have led to the hypothesis that melatonin consumption can be effective in SARS-CoV-2 patients. However, more clinical trials are needed to exactly evaluate the mechanism of action and efficacy of Melatonin in COVID19 patients [112]. Diverse fates which may occur for Melatonin when interacting with host cells are exhibited in Fig. 5.

The most important information on the discussed immunomodulatory drugs used for COVID-19 treatment, along modulate the expression of pro-inflammatory genes such as NF-K $\beta$ and thus affect cytokines synthesis. It also exerts its anti-inflammatory effects through other mechanisms

with the possible mechanism of action, their adverse effects, etc. is presented in Table 1.

\section{Conclusion}

COVID-19 as a respiratory disease has been continuously evolving, highlighting the need for constant research and proper measures. Recently, having been caused by mutations in SARS-CoV-2, new variants are being discovered [159]. Although vaccines can be successful in immunizing individuals against COVID-19, they seem to be not suitable for hospitalized patients with severe and critical conditions. Immune dysfunction and especially over activation of the 


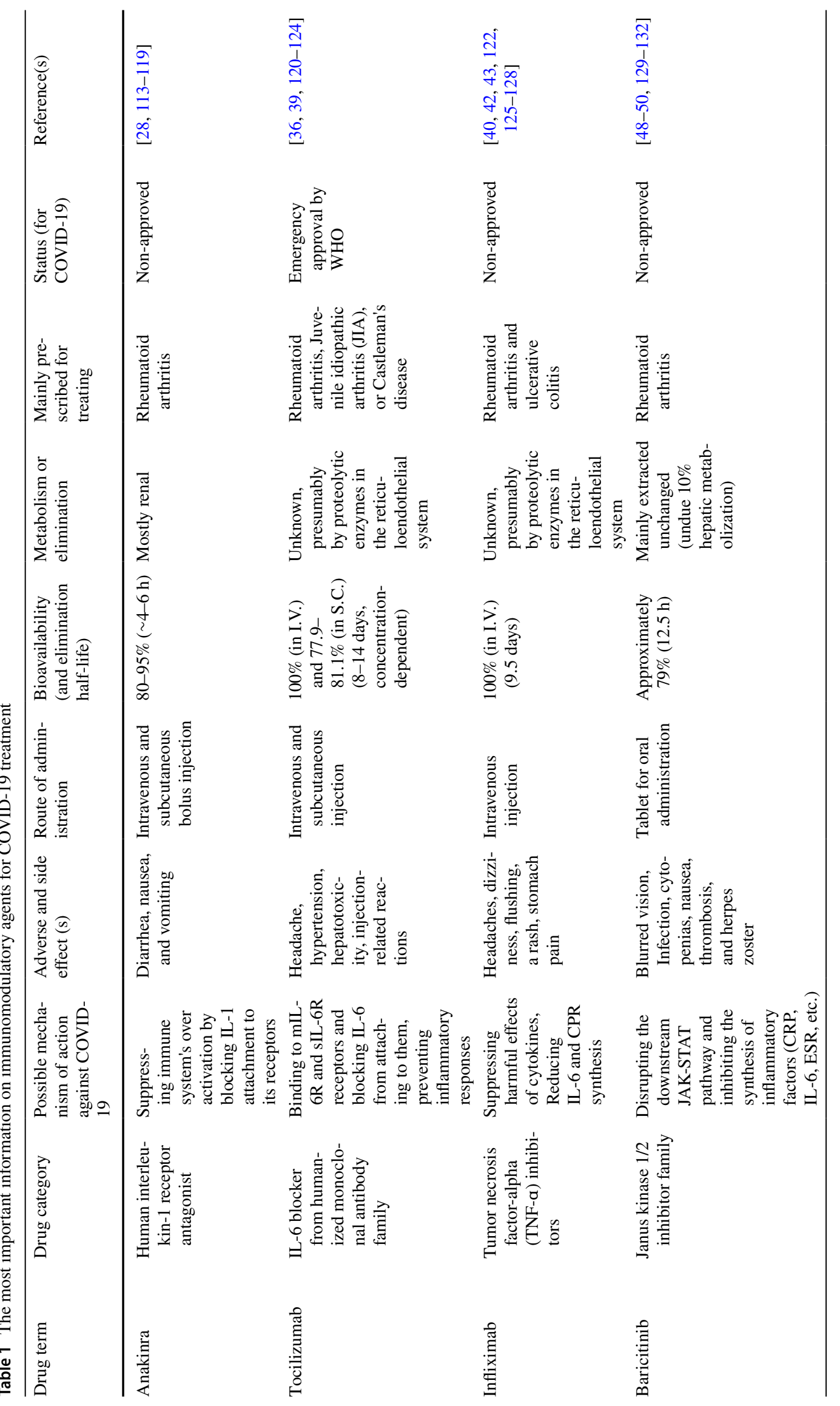




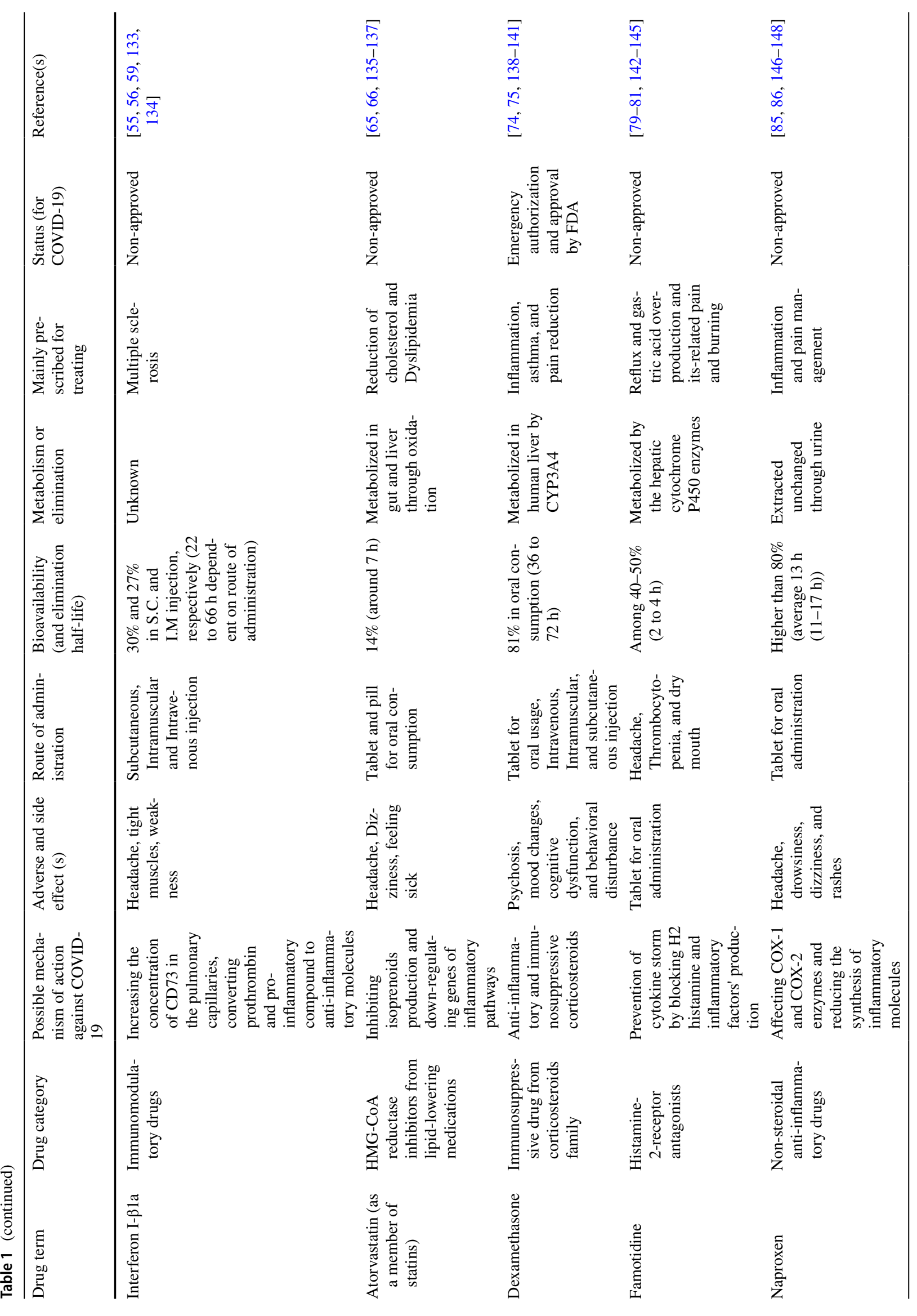




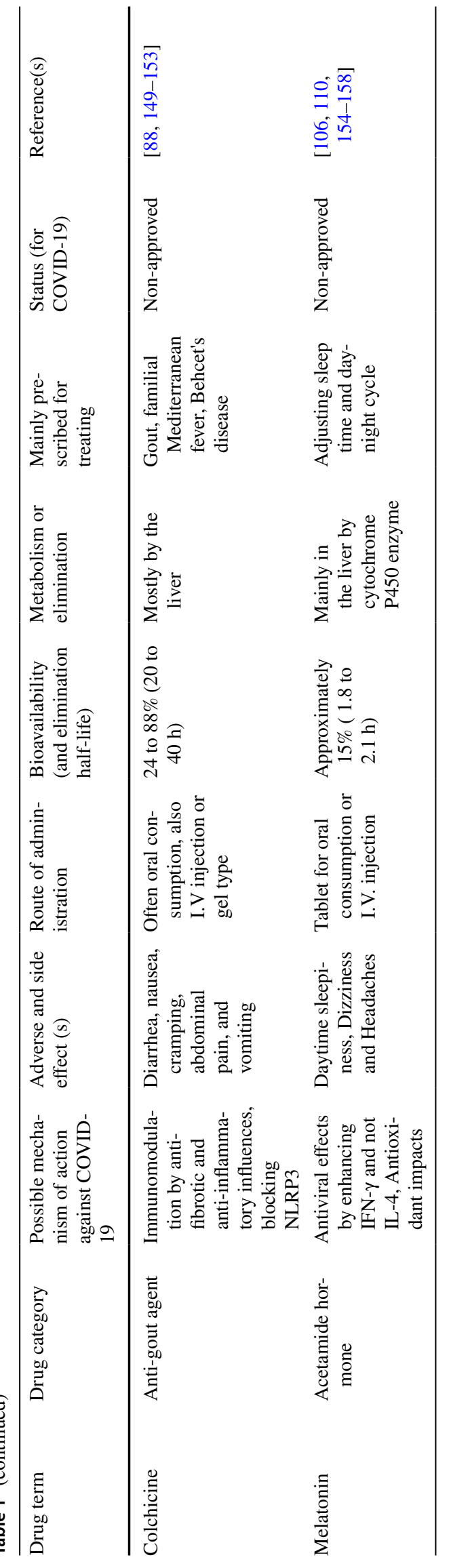

immune system and lymphopenia are two significant problems in COVID-19 patients [160]. In this regard, the application of immunomodulatory drugs has been considered to reduce the mortality rate in COVID-19 patients. In the present review article, the mechanism of action for several pivotal immunomodulatory and immunosuppressant agents pertaining to different drug groups was examined and discussed. More studies and extensive trials are warranted to ensure the extent of effectiveness or ineffectiveness of these medications. The outcomes of this study, however, can assist physicians and scientists in designing future studies and having better treatment guidelines.

Acknowledgements Not applicable.

Authors contributions FR and MJN contributed to conceptualization and investigations. FR did writing-original draft, visualization, figures preparation, and literature search. MJN contributed to supervision and project administration. MM performed writing-review and editing.

Funding This review article received no grant, financial aid, or funding from any funding agency in the public, universities, or commercial sectors.

Data availability All data are available in the text of the article.

\section{Declarations}

Conflict of interest All authors declare that they have no conflict of interest.

Ethical approval Not applicable.

Consent to participate Not applicable.

Consent for publication Not applicable.

\section{References}

1. Velavan TP, Meyer CG (2020) The COVID-19 epidemic. Trop Med Int Health 25(3):278

2. Zhou P, Yang X-L, Wang X-G, Hu B, Zhang L, Zhang W, Si H-R, Zhu Y, Li B, Huang C-L (2020) A pneumonia outbreak associated with a new coronavirus of probable bat origin. Nature 579(7798):270-273

3. Ahmed SS (2020) The Coronavirus disease 2019 (COVID-19): a review. J Adv Med Medl Res. https://doi.org/10.9734/jammr/ 2020/v32i430393

4. Toniato E, Ross R, Kritas S (2020) How to reduce the likelihood of coronavirus-19 (CoV-19 or SARS-CoV-2) infection and lung inflammation mediated by IL-1. J Biol Regul Homeost Agents 34(2):11-16

5. Conti P, Younes A (2020) Coronavirus COV-19/SARS-CoV-2 affects women less than men: clinical response to viral infection. J Biol Regul Homeost Agents 34:339

6. Hageman JR (2020) The coronavirus disease 2019 (COVID-19). SLACK Incorporated, Thorofare, NJ

7. Pashaki PA, Roudkenar MH, Rahim F, Ebrahimi A (2020) From SARS-CoV to SARS-CoV2: a potential guide to better 
understanding of pathophysiology of the disease and potential therapeutic modality. Eur Rev Med Pharmacol Sci 24(14):7816

8. Hikmet F, Méar L, Edvinsson Å, Micke P, Uhlén M, Lindskog C (2020) The protein expression profile of ACE2 in human tissues. Mol Syst Biol 16(7):e9610

9. Fan C, Li K, Ding Y, Lu WL, Wang J (2020) ACE2 expression in kidney and testis may cause kidney and testis damage after 2019-nCoV infection. MedRxiv 71:9180

10. Salvi R, Patankar P (2020) Emerging pharmacotherapies for COVID-19. Biomed Pharmacother 128:110267

11. Guan W-J, Ni Z-Y, Hu Y, Liang W-H, Ou C-Q, He J-X, Liu L, Shan H, Lei C-L, Hui DS (2020) Clinical characteristics of coronavirus disease 2019 in China. N Engl J Med 382(18):1708-1720

12. Ronco C, Reis T, Husain-Syed F (2020) Management of acute kidney injury in patients with COVID-19. Lancet Respir Med 8(7):738-742

13. Li G, Fan Y, Lai Y, Han T, Li Z, Zhou P, Pan P, Wang W, Hu D, Liu X (2020) Coronavirus infections and immune responses. J Med Virol 92(4):424-432

14. Guizani I, Fourti N, Zidi W, Feki M, Allal-Elasmi M (2021) SARS-CoV-2 and pathological matrix remodeling mediators. Inflamm Res 12:43

15. Toldo S, Bussani R, Nuzzi V, Bonaventura A, Mauro AG, Cannatà A, Pillappa R, Sinagra G, Nana-Sinkam P, Sime P (2021) Inflammasome formation in the lungs of patients with fatal COVID-19. Inflamm Res 70(1):7-10

16. Cecere TE, Todd SM, LeRoith T (2012) Regulatory T cells in arterivirus and coronavirus infections: do they protect against disease or enhance it? Viruses 4(5):833-846

17. Maloir Q, Ghysen K, Von Frenckell C, Louis R, Guiot J (2018) Acute respiratory distress revealing antisynthetase syndrome. Rev Med Liege 73(7-8):370-375

18. Zhou Y, Fu B, Zheng X, Wang D, Zhao C, Qi Y, Sun R, Tian Z, Xu X, Wei H (2020) Pathogenic T-cells and inflammatory monocytes incite inflammatory storms in severe COVID-19 patients. Natl Sci Rev 7(6):998-1002

19. Pons S, Fodil S, Azoulay E, Zafrani L (2020) The vascular endothelium: the cornerstone of organ dysfunction in severe SARS-CoV-2 infection. Crit Care 24(1):1-8

20. Yeleswaram S, Smith P, Burn T, Covington M, Juvekar A, Li Y, Squier P, Langmuir P (2020) Inhibition of cytokine signaling by ruxolitinib and implications for COVID-19 treatment. Clin Immunol 218:108517

21. Owji H, Negahdaripour M, Hajighahramani N (2020) Immunotherapeutic approaches to curtail COVID-19. Int Immunopharmacol 88:106924

22. Mahase E (2021) Covid-19: Molnupiravir reduces risk of hospital admission or death by $50 \%$ in patients at risk, MSD reports. British Medical Journal Publishing Group, London

23. Rommasi F, Nasiri M, Mirsaiedi M (2021) Antiviral drugs proposed for COVID-19: action mechanism and pharmacological data. Eur Rev Med Pharmacol Sci 25(11):4163-4173

24. Furst DE (2004) Anakinra: review of recombinant human interleukin-I receptor antagonist in the treatment of rheumatoid arthritis. Clin Ther 26(12):1960-1975

25. Gabay C, Arend WP (1998) Treatment of rheumatoid arthritis with IL-1 inhibitors. Springer, Berlin, pp 229-246

26. Ragab D, Salah Eldin H, Taeimah M, Khattab R, Salem R (2020) The COVID-19 cytokine storm; what we know so far. Front Immunol 11:1446

27. Schiff MH (2000) Role of interleukin 1 and interleukin 1 receptor antagonist in the mediation of rheumatoid arthritis. Ann Rheum Dis 59(suppl 1):i103-i108

28. Arend WP (2001) In Cytokine imbalance in the pathogenesis of rheumatoid arthritis: the role of interleukin-1 receptor antagonist. Elsevier, Amsterdam, pp 1-6
29. Chang S, Wu J, Gong X (2004) Cloning of hIL-1Ra gene and its expression in E. coli. Xi bao yu fen zi mian yi xue za zhi Chin J Cell Mol Immunol 20(4):484-487

30. Arend WP, Welgus H, Thompson RC, Eisenberg S (1990) Biological properties of recombinant human monocyte-derived interleukin 1 receptor antagonist. J Clin Investig 85(5):1694-1697

31. Arend WP, Dayer J-M (1995) Inhibition of the production and effects of interleukin-1 and tumor necrosis factor alpha in rheumatoid arthritis. Arthr Rheum 38(2):151-160

32. Seckinger P, Yaron I, Meyer FA, Yaron M, Dayer JM (1990) Modulation of the effects of interleukin-1 on glycosaminoglycan synthesis by the urine-derived interleukin-1 inhibitor, but not by interleukin-6. Arthr Rheum 33(12):1807-1814

33. Huet T, Beaussier H, Voisin O, Jouveshomme S, Dauriat G, Lazareth I, Sacco E, Naccache J-M, Bézie Y, Laplanche S (2020) Anakinra for severe forms of COVID-19: a cohort study. Lancet Rheumatol 2(7):e393-e400

34. Hedrick TL, Murray BP, Hagan RS, Mock JR (2020) COVID-19: clean up on IL-6. Am J Respir Cell Mol Biol 63(4):541-543

35. Rose-John S (2012) IL-6 trans-signaling via the soluble IL-6 receptor: importance for the pro-inflammatory activities of IL-6. Int J Biol Sci 8(9):1237

36. Braun GS, Nagayama Y, Maruta Y, Heymann F, van Roeyen CR, Klinkhammer BM, Boor P, Villa L, Salant DJ, Raffetseder U (2016) IL-6 trans-signaling drives murine crescentic GN. J Am Soc Nephrol 27(1):132-142

37. Kang S, Tanaka T, Narazaki M, Kishimoto T (2019) Targeting interleukin-6 signaling in clinic. Immunity 50(4):1007-1023

38. Jones SA, Jenkins BJ (2018) Recent insights into targeting the IL-6 cytokine family in inflammatory diseases and cancer. Nat Rev Immunol 18(12):773-789

39. Saha A, Sharma AR, Bhattacharya M, Sharma G, Lee S-S, Chakraborty C (2020) Tocilizumab: a therapeutic option for the treatment of cytokine storm syndrome in COVID-19. Arch Med Res 51:595

40. Knight DM, Trinh H, Le J, Siegel S, Shealy D, McDonough M, Scallon B, Moore MA, Vilcek J, Daddona P (1993) Construction and initial characterization of a mouse-human chimeric anti-TNF antibody. Mol Immunol 30(16):1443-1453

41. Siegel SA, Shealy DJ, Nakada MT, Le J, Woulfe DS, Probert L, Kollias G, Ghrayeb J, Vilcek J, Daddona PE (1995) The mouse/ human chimeric monoclonal antibody cA2 neutralizes TNF in vitro and protects transgenic mice from cachexia and TNF lethality in vivo. Cytokine 7(1):15-25

42. Maini RN, Feldmann M (2002) How does Infliximab work in rheumatoid arthritis? Arthr Res Ther 4(2):1-7

43. Elliott MJ, Maini RN, Feldmann M, Long-Fox A, Charles P, Katsikis P, Brennan FM, Walker J, Bijl H, Ghrayeb J (1993) Treatment of rheumatoid arthritis with chimeric monoclonal antibodies to tumor necrosis factor $\alpha$. Arthritis Rheum 36(12):1681-1690

44. Ulfgren AK, Andersson U, Engström M, Klareskog L, Maini RN, Taylor PC (2000) Systemic anti-tumor necrosis factor $\alpha$ therapy in rheumatoid arthritis down-regulates synovial tumor necrosis factor $\alpha$ synthesis. Arthr Rheum 43(11):2391-2396

45. Charles P, Elliott MJ, Davis D, Potter A, Kalden JR, Antoni C, Breedveld FC, Smolen JS, Eberl G, deWoody K (1999) Regulation of cytokines, cytokine inhibitors, and acute-phase proteins following anti-TNF- $\alpha$ therapy in rheumatoid arthritis. J Immunol 163(3): 1521-1528

46. Farrokhpour M, Rezaie N, Moradi N, Rad FG, Izadi S, Azimi M, Zamani F, Izadi S, Ranjbar M, Makiani MJ (2021) Infliximab and intravenous Gammaglobulin in hospitalized severe COVID-19 patients in intensive care unit. Arch Iran Med 24(2):139-143

47. Coperchini F, Chiovato L, Croce L, Magri F, Rotondi M (2020) The cytokine storm in COVID-19: an overview of the 
involvement of the chemokine/chemokine-receptor system. Cytokine Growth Factor Rev 53:25-32

48. Richardson P, Griffin I, Tucker C, Smith D, Oechsle O, Phelan A, Stebbing J (2020) Baricitinib as potential treatment for 2019-nCoV acute respiratory disease. Lancet (Lond, Engl) 395(10223):e30

49. Stebbing J, Phelan A, Griffin I, Tucker C, Oechsle O, Smith D, Richardson P (2020) COVID-19: combining antiviral and antiinflammatory treatments. Lancet Infect Dis 20(4):400-402

50. Titanji BK, Farley MM, Mehta A, Connor-Schuler R, Moanna A, Cribbs SK, O'Shea J, DeSilva K, Chan B, Edwards A (2020) Use of baricitinib in patients with moderate and severe COVID-19. Clin Infect Dis 72:1247

51. World Health Organization (WHO) (2020) Coronavirus disease (COVID-19) Situation Report-145. https://www.who.int/docs/ default-source/coronaviruse/situation-reports/20200613-covid19-sitrep-145.pdf?sfvrsn=bb7c1dc9_2. Accessed 27 July 2021

52. Raftery N, Stevenson NJ (2017) Advances in antiviral immune defence: revealing the importance of the IFN JAK/STAT pathway. Cell Mol Life Sci 74(14):2525-2535

53. Mehta P, McAuley DF, Brown M, Sanchez E, Tattersall RS, Manson JJ, Collaboration HAS (2020) COVID-19: consider cytokine storm syndromes and immunosuppression. Lancet (Lond, Engl) 395(10229):1033

54. Cheung KS, Hung IF, Chan PP, Lung K, Tso E, Liu R, Ng Y, Chu MY, Chung TW, Tam AR (2020) Gastrointestinal manifestations of SARS-CoV-2 infection and virus load in fecal samples from the Hong Kong cohort and systematic review and meta-analysis. Gastroenterology 159:81

55. Vermersch P, De Seze J, Delisse B, Lemaire S, Stojkovic T (2002) Quality of life in multiple sclerosis: influence of interferon- $\beta 1$ a (Avonex ${ }^{\circledR}$ ) treatment. Mult Scler J 8(5):377-381

56. Sallard E, Lescure F-X, Yazdanpanah Y, Mentre F, PeifferSmadja N, Florence A, Yazdanpanah Y, Mentre F, Lescure F-X, Peiffer-Smadja N (2020) Type 1 interferons as a potential treatment against COVID-19. Antiviral Res 178:104791

57. Mager DE, Jusko WJ (2002) Receptor-mediated pharmacokinetic/pharmacodynamic model of interferon- $\beta$ 1a in humans. Pharm Res 19(10):1537-1543

58. Varga Z, Flammer AJ, Steiger P, Haberecker M, Andermatt R, Zinkernagel AS, Mehra MR, Schuepbach RA, Ruschitzka F, Moch H (2020) Endothelial cell infection and endotheliitis in COVID-19. Lancet 395(10234): 1417-1418

59. Eltzschig HK, Sitkovsky MV, Robson SC (2012) Purinergic signaling during inflammation. N Engl J Med 367(24):2322-2333

60. Laver T, Nozell SE, Benveniste EN (2008) IFN- $\beta$-mediated inhibition of IL-8 expression requires the ISGF3 components Stat1, Stat2, and IRF-9. J Interferon Cytokine Res 28(1):13-23

61. Kiss J, Yegutkin GG, Koskinen K, Savunen T, Jalkanen S, Salmi M (2007) IFN- $\beta$ protects from vascular leakage via up-regulation of CD73. Eur J Immunol 37(12):3334-3338

62. Jalkanen J, Pettilä V, Huttunen T, Hollmén M, Jalkanen S (2020) Glucocorticoids inhibit type I IFN beta signaling and the upregulation of CD73 in human lung. Intensiv Care Med 5:524

63. Jalkanen J, Hollmén M, Jalkanen S (2020) Interferon beta-1a for COVID-19: critical importance of the administration route. Crit Care 24(1):1-3

64. Tahamtan S, Shirban F, Bagherniya M, Johnston TP, Sahebkar A (2020) The effects of statins on dental and oral health: a review of preclinical and clinical studies. J Transl Med 18(1):1-42

65. Castiglione V, Chiriacò M, Emdin M, Taddei S, Vergaro G (2020) Statin therapy in COVID-19 infection. Eur Heart J Cardiovasc Pharmacother 6:258

66. Zeiser R (2018) Immune modulatory effects of statins. Immunology 154(1):69-75
67. Yuan X, Deng Y, Guo X, Shang J, Zhu D, Liu H (2014) Atorvastatin attenuates myocardial remodeling induced by chronic intermittent hypoxia in rats: partly involvement of TLR-4/MYD88 pathway. Biochem Biophys Res Commun 446(1):292-297

68. Chansrichavala P, Chantharaksri U, Sritara P, Chaiyaroj SC (2009) Atorvastatin attenuates TLR4-mediated NF-[kappa] B activation in a MyD88-dependent pathway. Asian Pac J Allergy Immunol 27(1):49

69. Fedson D, Opal S, Rordam O (2020) Treating patients with severe COVID-19 infection. MBio 11(2):e00398-e00420

70. McKenney JM (2003) Pharmacologic characteristics of statins. Clin Cardiol 26(S3):32-38

71. Theoharides T, Conti P (2020) Dexamethasone for COVID-19? Not so fast. J Biol Regul Homeost Agents 34(3):10.23812

72. Poon LL, Peiris M (2020) Emergence of a novel human coronavirus threatening human health. Nat Med 26(3):317-319

73. Chen G, Wu D, Guo W, Cao Y, Huang D, Wang H, Wang T, Zhang X, Chen H, Yu H (2020) Clinical and immunological features of severe and moderate coronavirus disease 2019. J Clin Investig 130(5):2620

74. Giles AJ, Hutchinson M-KN, Sonnemann HM, Jung J, Fecci PE, Ratnam NM, Zhang W, Song H, Bailey R, Davis D (2018) Dexamethasone-induced immunosuppression: mechanisms and implications for immunotherapy. J Immunother Cancer 6(1):1-13

75. Chen H, Wang F, Zhang P, Zhang Y, Chen Y, Fan X, Cao X, Liu J, Yang Y, Wang B (2019) Management of cytokine release syndrome related to CAR-T cell therapy. Front Med 13(5):610-617

76. Beigel JH, Tomashek KM, Dodd LE, Mehta AK, Zingman BS, Kalil AC, Hohmann E, Chu HY, Luetkemeyer A, Kline S (2020) Remdesivir for the treatment of Covid-19-preliminary report. N Engl J Med 383:1813

77. Merad M, Martin JC (2020) Pathological inflammation in patients with COVID-19: a key role for monocytes and macrophages. Nat Rev Immunol 20:355

78. Theoharides TC (2020) COVID-19, pulmonary mast cells, cytokine storms, and beneficial actions of luteolin. Biofactors (Oxf, Engl) 46:306

79. Hogan RB II, Hogan RB III, Cannon T, Rappai M, Studdard J, Paul D, Dooley TP (2020) Dual-histamine receptor blockade with cetirizine-famotidine reduces pulmonary symptoms in COVID-19 patients. Pulm Pharmacol Ther 63:101942

80. Kmiecik T, Otocka-Kmiecik A, Górska-Ciebiada M, Ciebiada M (2012) T lymphocytes as a target of histamine action. Arch Med Sci AMS 8(1):154

81. Branco ACCC, Yoshikawa FSY, Pietrobon AJ, Sato MN (2018) Role of histamine in modulating the immune response and inflammation. Mediat Inflamm 2018:1-10

82. Maddali MM, Mathew M, Chandwani J, Alsajwani MJ, Ganguly SS (2011) Outcomes after rigid bronchoscopy in children with suspected or confirmed foreign body aspiration: a retrospective study. J Cardiothorac Vasc Anesth 25(6):1005-1008

83. Todd PA, Clissold SP (1990) Naproxen. Drugs 40(1):91-137

84. American Society of Health-System Pharmacists (ASHP) (2021) Naproxen. https://www.drugs.com/monograph/naproxen.html. Accessed 11 Aug 2021

85. Khoury CK, Couch JR (2010) Sumatriptan-Naproxen fixed combination for acute treatment of migraine: a critical appraisal. Drug Des Dev Ther 4:9

86. Duggan KC, Walters MJ, Musee J, Harp JM, Kiefer JR, Oates JA, Marnett LJ (2010) Molecular basis for cyclooxygenase inhibition by the non-steroidal anti-inflammatory drug naproxen. J Biol Chem 285(45):34950-34959

87. Moore N, Charlesworth A, Van Ganse E, LeParc JM, Jones JK, Wall R, Schneid H, Verriere F (2003) Risk factors for adverse events in analgesic drug users: results from the PAIN study. Pharmacoepidemiol Drug Saf 12(7):601-610 
88. Leung YY, Hui LLY, Kraus VB (2015) In Colchicine-update on mechanisms of action and therapeutic uses. Elsevier, Amsterdam, pp 341-350

89. Nuki G (2008) Colchicine: its mechanism of action and efficacy in crystal-induced inflammation. Curr Rheumatol Rep 10(3):218-227

90. Phelps P (1970) Polymorphonuclear leukocyte motility in vitro. IV. Colchicine inhibition of chemotactic activity formation after phagocytosis of urate crystals. Arthr Rheum 13(1):1-9

91. Mizumoto N, Gao J, Matsushima H, Ogawa Y, Tanaka H, Takashima A (2005) Discovery of novel immunostimulants by dendritic-cell-based functional screening. Blood 106(9):3082-3089

92. Mizumoto N, Tanaka H, Matsushima H, Vishwanath M, Takashima A (2007) Colchicine promotes antigen crosspresentation by murine dendritic cells. J Investig Dermatol 127(6):1543-1546

93. Marin-Esteban V, Charron D, Gelin C, Mooney N (2010) Chemotherapeutic agents targeting the tubulin cytoskeleton modify LPS-induced cytokine secretion by dendritic cells and increase antigen presentation. J Immunother 33(4):364-370

94. Li C, Yang CW, Ahn HJ, Kim WY, Park CW, Park JH, Lee MJ, Yang JH, Kim Y-S, Bang BK (2002) Colchicine decreases apoptotic cell death in chronic cyclosporine nephrotoxicity. J Lab Clin Med 139(6):364-371

95. Sandbo N, Ngam C, Torr E, Kregel S, Kach J, Dulin N (2013) Control of myofibroblast differentiation by microtubule dynamics through a regulated localization of $\mathrm{mDia} 2$. J Biol Chem 288(22):15466-15473

96. Schlesinger N, Firestein BL, Brunetti L (2020) Colchicine in COVID-19: an old drug, new use. Curr Pharmacol Rep 6(4):137-145

97. Tardif J-C, Bouabdallaoui N, L'Allier PL, Gaudet D, Shah B, Pillinger MH, Lopez-Sendon J, da Luz P, Verret L, Audet S (2021) Efficacy of colchicine in non-hospitalized patients with COVID-19. Medrxiv 30:1

98. Cumhur Cure M, Kucuk A, Cure E (2020) Colchicine may not be effective in COVID-19 infection; it may even be harmful? Clin Rheumatol 39:2101-2102

99. Lee JG, Woo YS, Park SW, Seog D-H, Seo MK, Bahk W-M (2019) The neuroprotective effects of Melatonin: possible role in the pathophysiology of neuropsychiatric disease. Brain Sci 9(10):285

100. Masters A, Pandi-Perumal SR, Seixas A, Girardin J-L, McFarlane SI (2014) Melatonin, the hormone of darkness: from sleep promotion to ebola treatment. Brain Disord Ther 4(1):1000151

101. Auld F, Maschauer E, Morrison I, Skene D, Riha R, Riha RL (2016) Sincere thanks to Lisa Wood and Tomas Ray for assistance with editing. Conflicts of interest-None

102. Carretero M, Escames G, López LC, Venegas C, Dayoub JC, Garcia L, Acuña-Castroviejo D (2009) Long-term melatonin administration protects brain mitochondria from aging. J Pineal Res 47(2):192-200

103. Zhao D, Yu Y, Shen Y, Liu Q, Zhao Z, Sharma R, Reiter RJ (2019) Melatonin synthesis and function: evolutionary history in animals and plants. Front Endocrinol 10:249

104. Iguchi H, Kato K-I, Ibayashi H (1982) Age-dependent reduction in serum melatonin concentrations in healthy human subjects. J Clin Endocrinol Metab 55(1):27-29

105. Maestroni GJ (2001) The immunotherapeutic potential of Melatonin. Expert Opin Investig Drugs 10(3):467-476

106. Garcia-Maurino S, Gonzalez-Haba MG, Calvo JR, Rafii-ElIdrissi M, Sanchez-Margalet V, Goberna R, Guerrero JM (1997) Melatonin enhances IL-2, IL-6, and IFN-gamma production by human circulating CD4+ cells: a possible nuclear receptor-mediated mechanism involving $\mathrm{T}$ helper type 1 lymphocytes and monocytes. J Immunol 159(2):574-581

107. Grandvaux N, Servant MJ, Hiscott J (2002) The interferon antiviral response: from viral invasion to evasion. Curr Opin Infect Dis 15(3):259-267

108. Khomich OA, Kochetkov SN, Bartosch B, Ivanov AV (2018) Redox biology of respiratory viral infections. Viruses 10(8):392

109. Vijay R, Hua X, Meyerholz DK, Miki Y, Yamamoto K, Gelb M, Murakami M, Perlman S (2015) Critical role of phospholipase A2 group IID in age-related susceptibility to severe acute respiratory syndrome-CoV infection. J Exp Med 212(11):1851-1868

110. Tan DX, Manchester LC, Terron MP, Flores LJ, Reiter RJ (2007) One molecule, many derivatives: a never-ending interaction of Melatonin with reactive oxygen and nitrogen species? J Pineal Res 42(1):28-42

111. Constantinescu C, Hilliard B, Ventura E, Rostami A (1997) Luzindole, a melatonin receptor antagonist, suppresses experimental autoimmune encephalomyelitis. Pathobiology 65(4):190-194

112. Kleszczyński K, Slominski AT, Steinbrink K, Reiter RJ (2020) Clinical trials for use of melatonin to fight against COVID-19 are urgently needed. Nutrients 12(9):2561

113. Whiteley A, Becerra C, McCollum D, Paulson AS, Goel A (2016) A pilot, non-randomized evaluation of the safety of anakinra plus FOLFIRINOX in metastatic pancreatic ductal adenocarcinoma patients. Am Soc Clin Oncol 34:e15750

114. Alpa M (2015) Anakinra/colchicine. Reactions 1580:32-35

115. Yang BB, Baughman S, Sullivan JT (2003) Pharmacokinetics of anakinra in subjects with different levels of renal function. Clin Pharmacol Ther 74(1):85-94

116. Mertens M, Singh JA (2009) Anakinra for rheumatoid arthritis: a systematic review. J Rheumatol 36(6):1118-1125

117. King A, Vail A, O'Leary C, Hannan C, Brough D, Patel H, Galea J, Ogungbenro K, Wright M, Pathmanaban O (2020) Anakinra in COVID-19: important considerations for clinical trials. Lancet Rheumatol 2(7):e379-e381

118. Muñoz-Jiménez A, Rubio-Romero E, de la Fuente JLM (2021) Proposal for the use of anakinra in acute respiratory distress secondary to COVID-19. Reumatol Clín (English Edit) 17(6):309-312

119. Kahn PJ, Cron RQ (2013) Higher-dose Anakinra is effective in a case of medically refractory macrophage activation syndrome. J Rheumatol 40(5):743-744

120. Magro G (2020) COVID-19: review on latest available drugs and therapies against SARS-CoV-2. Coagulation and inflammation cross-talking. Virus Res 286:198070

121. Tanaka T, Narazaki M, Kishimoto T (2011) Anti-interleukin-6 receptor antibody, Tocilizumab, for the treatment of autoimmune diseases. FEBS Lett 585(23):3699-3709

122. Keizer R, Huitema AD, Schellens JH, Beijnen JH (2010) Clinical pharmacokinetics of therapeutic monoclonal antibodies. Clin Pharmacokinet 49:493-507

123. Tanaka T, Ogata A, Narazaki M (2010) Tocilizumab for the treatment of rheumatoid arthritis. Expert Rev Clin Immunol 6(6):843-854

124. Abdallah H, Hsu JC, Lu P, Fettner S, Zhang X, Douglass W, Bao M, Rowell L, Burmester GR, Kivitz A (2017) Pharmacokinetic and pharmacodynamic analysis of subcutaneous Tocilizumab in patients with rheumatoid arthritis from 2 randomized, controlled trials: SUMMACTA and BREVACTA. J Clin Pharmacol 57(4):459-468

125. Connor V (2011) Anti-TNF therapies: a comprehensive analysis of adverse effects associated with immunosuppression. Rheumatol Int 31(3):327-337

126. Lopetuso LR, Petito V, Cufino V, Arena V, Stigliano E, Gerardi V, Gaetani E, Poscia A, Amato A, Cammarota G (2013) Locally 
injected Infliximab ameliorates murine DSS colitis: differences in serum and intestinal levels of drug between healthy and colitic mice. Dig Liver Dis 45(12):1017-1021

127. Akiho H, Yokoyama A, Abe S, Nakazono Y, Murakami M, Otsuka Y, Fukawa K, Esaki M, Niina Y, Ogino H (2015) Promising biological therapies for ulcerative colitis: a review of the literature. World J Gastrointest Pathophysiol 6(4):219

128. Bendtzen K, Geborek P, Svenson M, Larsson L, Kapetanovic MC, Saxne T (2006) Individualized monitoring of drug bioavailability and immunogenicity in rheumatoid arthritis patients treated with the tumor necrosis factor $\alpha$ inhibitor infliximab. Arthr Rheum 54(12):3782-3789

129. Bethesda (2012) LiverTox: Clinical and Research Information on Drug-Induced Liver Injury. https://www.ncbi.nlm.nih.gov/books/ NBK548012/. Accessed 10 Nov 2021

130. Damsky W, Peterson D, Ramseier J, Al-Bawardy B, Chun H, Proctor D, Strand V, Flavell RA, King B (2021) The emerging role of Janus kinase inhibitors in the treatment of autoimmune and inflammatory diseases. J Allergy Clin Immunol 147(3):814-826

131. Lilly E (2019) Baricitinib for rheumatoid arthritis. Aust Prescr 42(1):34-35

132. National Center for Biotechnology Information (2021) PubChem Compound Summary for CID 44205240, Baricitinib. https:// pubchem.ncbi.nlm.nih.gov/compound/Baricitinib. Accessed 10 Nov 2021

133. De Massougnes $S$ (2016) Interferon- $\beta-1 \mathrm{a}$. Reactions 1611:106-123

134. Buchwalder P-A, Buclin T, Trinchard I, Munafo A, Biollaz J (2000) Pharmacokinetics and pharmacodynamics of IFN- $\beta 1 \mathrm{a}$ in healthy volunteers. J Interferon Cytokine Res 20(10):857-866

135. Sirtori CR (2014) The pharmacology of statins. Pharmacol Res 88:3-11

136. Khan FN, Dehghan MHG (2011) Enhanced bioavailability of atorvastatin calcium from stabilized gastric resident formulation. AAPS PharmSciTech 12(4):1077-1086

137. Lennernäs $H$ (2003) Clinical pharmacokinetics of atorvastatin. Clin Pharmacokinet 42(13):1141-1160

138. Morganstein S, Morganstein D, Morganstein L (2020) Dexamethasone caution. Br Dent J 229(7):398-398

139. Tomlinson E, Maggs J, Park B, Back D (1997) Dexamethasone metabolism in vitro: species differences. J Steroid Biochem Mol Biol 62(4):345-352

140. Cronin J, Kennedy U, McCoy S, an Fhailí SN, CrispinoO'Connell G, Hayden J, Wakai A, Walsh S, O'Sullivan R (2012) Single dose oral dexamethasone versus multi-dose prednisolone in the treatment of acute exacerbations of asthma in children who attend the emergency department: study protocol for a randomized controlled trial. Trials 13(1):1-11

141. Spoorenberg SM, Deneer VH, Grutters JC, Pulles AE, Voorn G, Rijkers GT, Bos WJW, van de Garde EM (2014) Pharmacokinetics of oral vs. intravenous Dexamethasone in patients hospitalized with community-acquired pneumonia. Br J Clin Pharmacol 78(1):78-83

142. Cox DR, Wise SK (2018) Medical treatment of nasal airway obstruction. Otolaryngol Clin North Am 51(5):897-908

143. Nguyen K, Dersnah GD, Ahlawat R (2020) Famotidine. In: StatPearls [Internet]. StatPearls Publishing, Treasure Island
144. Echizen H, Ishizaki T (1991) Clinical pharmacokinetics of famotidine. Clin Pharmacokinet 21(3):178-194

145. Chremos A (1987) Clinical pharmacology of famotidine: a summary. J Clin Gastroenterol 9:7-12

146. Capone ML, Tacconelli S, Sciulli MG, Anzellotti P, Di Francesco L, Merciaro G, Di Gregorio P, Patrignani P (2007) Human pharmacology of naproxen sodium. J Pharmacol Exp Ther 322(2):453-460

147. Segre E (1980) Naproxen sodium (Anaprox): pharmacology, pharmacokinetics and drug interactions. J Reprod Med 25(4 Suppl):222-225

148. Calvo M, Lanao J, Dominguez-Gil A (1987) Bioavailability of rectally administered Naproxen. Int J Pharm 38(1-3):117-122

149. Rochdi M, Sabouraud A, Girre C, Venet R, Scherrmann J (1994) Pharmacokinetics and absolute bioavailability of Colchicine after iv and oral administration in healthy human volunteers and elderly subjects. Eur J Clin Pharmacol 46(4):351-354

150. Grimaitre M, Etienne A, Fathi M, Piletta P-A, Saurat J-H (2000) Topical colchicine therapy for actinic keratoses. Dermatology 200(4):346-348

151. Lev S, Snyder D, Azran C, Zolotarsky V, Dahan A (2017) Severe hypertriglyceridemia and Colchicine intoxication following suicide attempt. Drug Des Dev Ther 11:3321

152. Chappey O, Scherrmann J (1995) Colchicine: recent data on pharmacokinetics and clinical pharmacology. Rev Med Interne 16(10):782-789

153. Finkelstein Y, Aks SE, Hutson JR, Juurlink DN, Nguyen P, Dubnov-Raz G, Pollak U, Koren G, Bentur Y (2010) Colchicine poisoning: the dark side of an ancient drug. Clin Toxicol 48(5):407-414

154. Bauer B (2017) Melatonin side effects: what are the risks. Mayo Clin 10

155. Zetner DB, Andersen LPK, Rosenberg J. Pharmacokinetics of intravenous, rectal, intravesical, vaginal, and transdermal administration of exogenous Melatonin in healthy female volunteers: a crossover study

156. Tordjman S, Chokron S, Delorme R, Charrier A, Bellissant E, Jaafari N, Fougerou C (2017) Melatonin: pharmacology, functions and therapeutic benefits. Curr Neuropharmacol 15(3):434-443

157. DeMuro RL, Nafziger AN, Blask DE, Menhinick AM, Bertino JS Jr (2000) The absolute bioavailability of oral melatonin. J Clin Pharmacol 40(7):781-784

158. Gooneratne NS, Edwards AY, Zhou C, Cuellar N, Grandner MA, Barrett JS (2012) Melatonin pharmacokinetics following two different oral surge-sustained release doses in older adults. J Pineal Res 52(4):437-445

159. van Oosterhout C, Hall N, Ly H, Tyler KM (2021) COVID-19 evolution during the pandemic-implications of new SARSCoV-2 variants on disease control and public health policies. Taylor \& Francis, Routledge

160. Gendelman O, Amital H, Bragazzi NL, Watad A, Chodick G (2020) Continuous Hydroxychloroquine or colchicine therapy does not prevent infection with SARS-CoV-2: insights from a large healthcare database analysis. Autoimmun Rev 19(7):102566

Publisher's Note Springer Nature remains neutral with regard to jurisdictional claims in published maps and institutional affiliations. 